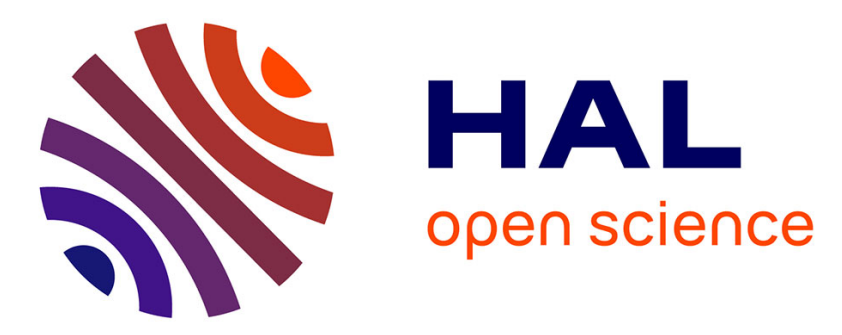

\title{
Estimating balanced structure areas in multi-species forests on the Sierra Madre Occidental, Mexico
}

Wehenkel, José Corral-Rivas, José Hernández-Díaz, Gadow

\section{To cite this version:}

Wehenkel, José Corral-Rivas, José Hernández-Díaz, Gadow. Estimating balanced structure areas in multi-species forests on the Sierra Madre Occidental, Mexico. Annals of Forest Science, 2011, 68 (2), pp.385-394. 10.1007/s13595-011-0027-9 . hal-00930762

\section{HAL Id: hal-00930762 https://hal.science/hal-00930762}

Submitted on 1 Jan 2011

HAL is a multi-disciplinary open access archive for the deposit and dissemination of scientific research documents, whether they are published or not. The documents may come from teaching and research institutions in France or abroad, or from public or private research centers.
L'archive ouverte pluridisciplinaire HAL, est destinée au dépôt et à la diffusion de documents scientifiques de niveau recherche, publiés ou non, émanant des établissements d'enseignement et de recherche français ou étrangers, des laboratoires publics ou privés. 


\title{
Estimating balanced structure areas in multi-species forests on the Sierra Madre Occidental, Mexico
}

\author{
Christian Wehenkel • José Javier Corral-Rivas • \\ José Ciro Hernández-Díaz • Klaus von Gadow
}

Received: 4 January 2010 / Accepted: 23 July 2010 / Published online: 22 February 2011

(C) INRA and Springer Science+Business Media B.V. 2011

\begin{abstract}
- Introduction This study presents a method for estimating the minimum area which exhibits a balanced diameter distribution, and the corresponding number of trees, for different tree species and forest types in the Santiago Papasquiaro region in the State of Durango, Mexico. The balanced structure area is defined as the minimum contiguous area that is required for sustainable management of a multi-sized selection forest. A multi-sized forest represents a balanced structure unit if the relationship between harvest and growth can be maintained, using a defined target diameter distribution and disregarding major natural disturbances. The study is based on 17,577 sample plots in uneven-aged forests, which are selectively harvested by local communities.

- Results and discussion The minimum structure areas that provide a balanced diameter distribution in the diameter at breast height $(D B H)$ interval of 12 to $57 \mathrm{~cm}$ vary from 0.4 to $122 \mathrm{ha}$, depending on the particular tree species. This study has shown that it is possible to identify silvicultural treatments that are conducive to sustainable use.
\end{abstract}

Handling Editor: David E. Hibbs

C. Wehenkel $(\bowtie) \cdot J$. C. Hernández-Díaz

Instituto de Silvicultura e Industria de la Madera,

Universidad Juárez del Estado de Durango,

Km 5.5 Carretera Mazatlán,

34120 Durango, México

e-mail:wehenkel@ujed.mx

J. J. Corral-Rivas

Facultad de Ciencias Forestales,

Universidad Juárez del Estado de Durango,

Río Papaloapan y Blvd. Durango s/n, Col. Valle del Sur,

34120 Durango, México

K. von Gadow

Burckhardt Institut, Büsgenweg 5, Georg-August University,

37077 Göttingen, Germany
- Conclusion Future management monitoring in the unique forests of Durango will reveal unsustainable harvesting practices more effectively and in a more comprehensive way than before, using the methods presented in this study.

Keywords Diameter distribution - Sustainable management $\cdot$ Species diversity $\cdot$ Covariation $\cdot$ Permutation test $\cdot$ Uneven-aged silviculture $\cdot$ Selective harvesting

\section{Introduction}

\subsection{Sustainable forest management}

It is widely accepted that sustainable forest use should be based on principles of constancy and stability in contrast to overexploitation and depletion of a valuable resource to the detriment of future generations (Kotwal et al. 2008). This sounds logical, but the implementation of such general ideas represents a real challenge. For successful maintenance of an industry based on timber products, forest planning must ensure that there are always stands at the correct stage of development and in sufficient number to yield the desired product mix from the forest (Gadow and Puumalainen 2000). The classical approach in rotation management systems involves calculation of an allowable cutting volume based on the current growing stock and estimated growth.

In a forest managed under the selection system, forest development does not follow a cyclical harvest-andregeneration pattern. Instead, it oscillates around some ideal level of growing stock. Various techniques have been devised to ensure sustained production levels. The most common technique involves the definition of a residual growing stock or target structure that should remain after each harvest event. In theory, the approach is very simple and logical. By comparing the real and ideal diameter 
distributions, it is possible to determine the number of trees that should be harvested in each diameter class (see examples by Cancino and Gadow 2002). The accumulated surplus is removed on successive visits to a particular forest stand. The challenge is to define the "residual growing stock", not only by timber volume, but also in terms of forest structure and diversity.

Pine-oak forests cover $16 \%$ of the Mexican territory, comprising 31.8 million hectares in total (FAO 1998: 30.1 million hectares), and occur throughout the major mountain ranges of the Sierra Madre Occidental, the Sierra Madre Oriental, the Sierra Madre del Sur, and the Transvolcanic Belt (Rzedowski 1978). In total, $80 \%$ of the forest area is owned and managed by about 8,000 rural communities known as Ejidos and Comuninades who manage their land with some level of governmental control (Thoms and Betters 1998).

Regarding the extent and economic value of its forest resources, the State of Durango is the most important state in Mexico. It is ranked first in terms of pine growing stock (27.7\%), annual yield of coniferous roundwood (25.7\%) and other roundwood yields (37.6\%) nationwide (SRNyMA 2002). Timber resources in the State of Durango are estimated to amount to about one-quarter of the national resources of Mexico. Of the total surface area of Durango $(12,274,730 \mathrm{ha})$, about $4,900,000$ ha are covered by forests. The predominant types of forest are pine-oak stands, often mixed with Pseudotsuga, Arbutus, and Juniperus, among other tree species (Corral-Rivas 2006).

Most forests are managed selectively by local communities. Uneven-aged structures are more complex than evenaged structures and one of the most pressing research problems is the development of practical concepts for defining sustainable harvests. On the basis of traditional methods of harvest control in multi-aged forests, the diameter distribution may provide a useful management tool that can be used to ensure that the natural species diversity is maintained. Such a tool is urgently needed for the 30.1 million hectares of temperate multi-aged and species-rich pine, oak, and fir forests of Mexico (FAO 1998).

\subsection{Balanced structure areas}

Genetic diversity is crucial for forest sustainability and ecosystem stability and has therefore been identified as one of the criteria/indicators for the registration, certification, and audit of a sustainable forest-management system (Rajora 1999). A demographically balanced stem-number distribution, which describes some equilibrium of tree sizes, is also a classical indicator of sustainability (Schütz 2002; Buongiorno and Gilles 2003). Structural balance may be achieved by defining ideal tree size or tree species distributions. Regarding the latter, the species-area rela- tionship, which describes the increase in the number of species with increasing sample area may be helpful (Hubbell 2001). It is well known that within a particular geographical region, larger contiguous forest areas contain more species than smaller forest fragments. Lawton (1999) has referred to this relationship as one of the few fundamental laws in ecology, and several models have been proposed to describe the relationship (Williams 1995; Tjørve 2003). These models allow us to estimate the minimum area, i.e., the smallest area that is required to capture all the species occurring within a given contiguous region. Such estimates have been presented by Gadow and Hui (2007) for a range of forest ecosystems.

If it is possible to estimate the minimum species area, then by analogy, it should be possible to estimate the balanced structure area $(B S A)$, which has been defined by Koop (1981) as the minimum contiguous area that includes all tree developmental stages. The BSA can be considered as the minimum area required for sustainable management in a multi-sized selection forest (see p. 50 in Kurth 1994). A multi-sized stand represents a balanced structural unit if the relationship between harvest and growth can be maintained using a defined target diameter distribution and disregarding major natural disturbances (Seymour and Kenefic 1998). Sustainability is theoretically achieved in these stands because goods and services can be consistently produced over time (Nyland 2002). The BSA can therefore be used as an indicator of demographic sustainability based on tree communities.

In a balanced diameter distribution, the ratio between successive diameter at breast height $(D B H)$ classes is constant. This relationship characterizes the shape of the curve (Baker et al. 1996) and can be described by the negative exponential function (Meyer 1933). Alternatively, the so-called $B D q$ model, defined by a basal area level, maximum diameter, and $q$ factor, was proposed by Guldin (1991). Other differently shaped $D B H$ distributions have been found for natural forests (Goff and West 1975; Cancino and Gadow 2002; Westphal et al. 2006). Nevertheless, a common factor in diameter distributions in balanced unevenaged forests is that the relationship between the tree diameters and the number of trees is monotonic decreasing.

\subsection{Objective}

The objective of this study is to estimate the minimum area for sustainable management that exhibits a balanced structure irrespective of the shape of the diameter distribution. An additional objective is to study the relationship between the minimum number of trees required for a balanced structure $(B S N)$ and the stand density of a particular species. Forest density affects forest structure, especially through its effect on the growth of recruitment trees (Schütz 2002, 2006). 


\section{Materials and methods}

\subsection{The data set}

The study area is located in the Sierra Madre Occidental, in the north-western region of the State of Durango, Mexico (within geographical coordinates $24^{\circ} 30^{\prime} 59^{\prime \prime}-25^{\circ} 30^{\prime} 20^{\prime \prime} \mathrm{N}$ and $\left.106^{\circ} 25^{\prime} 00^{\prime \prime}-105^{\circ} 52^{\prime} 21^{\prime \prime} \mathrm{W}\right)$. The Sierra Madre Occidental pine-oak forests, classified as "Nearctic subtropical coniferous forests" (http://en.wikipedia.org/wiki/ Nearctic_ecozone) are particularly interesting, not only because they represent a unique ecosystem, but also because they are owned and managed by local communities, known as "Ejidos". The study covers about 250,000 ha of unevenaged pine-oak forests. The altitude above sea level fluctuates between 1,400 and $3,000 \mathrm{~m}$. The prevailing climate is temperate, with rainfall in summer, an annual average precipitation of $800-1,400 \mathrm{~mm}$, and an annual average temperature of $2-22^{\circ} \mathrm{C}$ (García 1989; Silva-Flores et al. 2010). These forests are mainly managed by selective removals, with only a small amount of shelterwood harvesting (less than 5\% of the productive forest area). Clear felling is almost unknown, and requires special management expertise.

The continuous-cover forest management system used in Durango is known as the Método Mexicano de Ordenación de Bosques Irregulares (MMOBI). It was developed in 1944 for uneven-aged forests and was first described in the management plan of the Atenquique forest in Jalisco (Rodríguez 1958). The theoretical basis of the MMOBI system has been described by Torres (2000), who assumes that tree growth is exponential and can be estimated from the compound interest formula (Corral-Rivas 2006).

Usually, the largest trees are harvested for timber and to create small openings, which are scattered throughout the stand. New regeneration thus follows harvest events. Tree selection is carried out in the field by professional foresters to meet economic goals, and to ensure long-term ecosystem sustainability, especially with regard to the protection of biodiversity.

In Durango State, a comprehensive monitoring inventory of the forest is carried out once in every cutting cycle, which varies from 10 to 15 years. Data from the last forest inventory, involving 17,577 circular sample plots, were used in this analysis. The plot size varied between 500, 1,000 , and $1,500 \mathrm{~m}^{2}$. The plots were assigned on a regular grid. Between three and six sample plots were located in each compartment, depending on the stand density and compartment area. The total area sampled amounts to 1,674 ha of uneven-aged pine-oak forest. In each sample plot, the tree species and the $D B H$ of all trees with a $D B H$ of at least $10 \mathrm{~cm}$ were assessed along with other variables. The site quality was expressed by the maximum tree height in each stand $\left(H_{\max }\right)$ regardless of the tree species (Kurth 1994).
The diameter measurements were grouped into 16 three-cm classes to detect irregularities in the $D B H$ distributions (Westphal et al. 2006). The lower and upper bound diameter class midpoints were 12 and $57 \mathrm{~cm}$, respectively.

\subsection{Quantitative analysis}

The methods presented in this section involve the calculation of the covariation of diameter distributions, testing for randomness, and determining a minimum viable population size.

\subsubsection{Covariation of a diameter distribution}

According to Gregorius et al. (2007), two variables $X$ and $Y$ exhibit a perfect covariation if one consistently increases or decreases as the other consistently increases. In our application, $X$ represents the tree diameter class midpoint and $Y$ represents the absolute or relative frequencies in the diameter classes. The Covariation $C$ of a diameter distribution is defined by:

$C=\frac{\sum_{i<j}\left(X_{i}-X_{j}\right) \cdot\left(Y_{i}-Y_{j}\right)}{\sum_{i<j}\left|\left(X_{i}-X_{j}\right) \cdot\left(Y_{i}-Y_{j}\right)\right|}$

The covariation may assume values between -1 and +1 . $C=1$ refers to a perfectly positive covariation and $C=-1$ to a perfectly negative covariation. $C$ is undefined if the denominator is zero. In the context of this analysis, a $\mathrm{DBH}$ class distribution is assumed to be perfectly balanced if the number of trees decreases with increasing tree size, i.e., if the covariation between the diameter class midpoints $D C$ and the corresponding absolute or relative class frequencies $N(C[D C \times N])$, equals -1 . In that case, the relationship between the diameter classes (specified in ascending order) and the numbers of trees in the diameter classes is perfectly balanced, regardless of the form of the $D B H$ distribution.

\subsubsection{Testing for randomness}

There is a possibility that the observed $C$ may be the result of random events. To evaluate this possibility, a one-sided permutation test with randomly chosen assignments of $N$ was performed. The percentages of observed $C$ values that were greater than or equal to the random $C$ values $(P(Z \geq C) \geq 0.05)$ were computed for 5,000 permutations.

\subsubsection{Minimum viable population}

Based on the results of previous studies and general practice in seed orchards, we assume that adult trees (with $D B H>20 \mathrm{~cm}$ ) produce seed and pollen and that at least 40 of such parent trees represent a minimum viable population 
$(M V P)$ to ensure that the genetic substance is sustainable. There are different opinions and strategies regarding the definition of an MVP. In principle, genetic variation increases with effective population size (Frankham 1996). According to Wright (1938), the minimum viable population of breeding individuals in an idealized population is that which shows the same amount of dispersion of allele frequencies under random genetic drift or the same amount of inbreeding as the population under consideration. Genetic diversity is also correlated with the minimum viable population, which Nunney and Campbell (1993) propose as being represented by the population size required to ensure between $90 \%$ and $95 \%$ probability of future survival of between 100 and 1,000 years. According to Bücking (2003), for an area of 50 ha, an old-growth stand meets the minimum area required in conservation biology for maintaining the long-term viability of gene pool in late-successional mesic tree species.

\subsubsection{Calculating the covariation}

For each tree species and $D B H$ distribution, the Covariation $(C[D C \times N])$, the $P$ value and the number of adult trees were calculated in each individual circular plot $i$.

1. If the $C[D C \times N]$ in plot $i$ was greater than -0.99 (i.e., for example -0.98$)$ or not significant $(P(Z \geq C) \geq 0.05)$ or the plot contained less than 40 individuals with $D B H$ exceeding $20 \mathrm{~cm}$, the data from the nearest neighboring plot $j$ were merged with those in plot $i$. The covariation, the $P$ value and the number of trees with a $D B H$ exceeding $20 \mathrm{~cm}$ were calculated for the combined plots $i$ and $j$.

2. If the covariation in the merged plot was greater than -0.99 or $P$ was not significant, or if the plot contained less than 40 individuals with $D B H$ 's exceeding $20 \mathrm{~cm}$, the data from the second nearest neighboring plot $j+1$ were joined with those in plot $i$. Again, the covariation, the $P$ value, and the number of trees with $D B H$ exceeding $20 \mathrm{~cm}$ were calculated for the original plot $i$ and the two neighboring plots $j$ and $j+1$.

This process of merging plots (not stands/strata represented by a set of plots) is repeated until the diameter distribution is balanced and the number of potential seed parents is sufficient. The total area and the number of trees in the united plot cluster, which was assumed to represent the minimum $B S A$ and the minimum balanced structure tree number $(B S N)$ for a particular tree species, were then determined. The procedure of aggregating plots to attain structural balance and viability was repeated for all individual circular plots. The $B S A$ and $B S N$ distributions, the mean minimum balanced structure areas (mean $B S A$ ), the mean minimum balanced tree numbers (mean $B S N$ ), the
95\% confidence intervals of minimum balanced structure areas $\left(B S A_{0.025} ; B S A_{0.975}\right)$ and minimum balanced structure tree numbers $\left(B S N_{0.025 ;} B S N_{0.975}\right)$, and the smallest and largest minimum balanced structure areas $\left(B S A_{\min } ; B S A_{\max }\right)$ and minimum balanced structure tree numbers $\left(B S N_{\text {min }}\right.$; $\left.B S N_{\max }\right)$ were calculated.

Furthermore, the covariation and error probabilities calculated from 5,000 permutations were used to assess the relationships between the mean minimum structure tree number (mean $B S N$ ) as well as the upper limit of the $95 \%$ confidence interval of the $B S N\left(B S N_{0.975}\right)$ and the relative frequency, the area (hectare), and the number of trees of all conifer and oak species per ha.

\subsection{Evaluating differences between empirical and model} distributions

To evaluate the goodness of fit of the estimated exponential function $\left(f=a \cdot e^{(b \cdot D C)}\right)$, the "genetic distance" proposed by Gregorius et al. (2007) was found most suitable because it is easily interpreted. The genetic distance is defined as follows:

$d=\frac{1}{2} \sum_{i=1}^{n}\left|p_{i}-q_{i}\right|$

where $n$ refers to the number of diameter classes, and $p_{i}$ and $q_{i}$ are the relative frequencies in the estimated and empirical distributions. $d$ may assume values of between zero and one. It is equal to the proportion of the diameter frequencies that must be exchanged so that the observed empirical distribution is exactly equal to the estimated exponential model distribution (Westphal et al. 2006; Corral-Rivas et al. 2009). Both distributions are identical if $d=0$, and they have nothing in common if $d=1$. A permutation test with 5,000 permutations was used to test the hypothesis that the empirical and the model distributions are statistically identical, at $a=0.05$.

\section{Results}

In this section, we present the global distribution of tree species and tree diameters, and the diameter distributions in different height classes.

\subsection{Global distribution of tree species and tree diameters}

The distribution of all trees with $D B H$ exceeding $10 \mathrm{~cm}$ in the 17,577 sample plots, is shown in Fig. 1, for all species. Three of the 61 species occurring in this temperate pineoak forest are obviously dominant. They are Pinus 


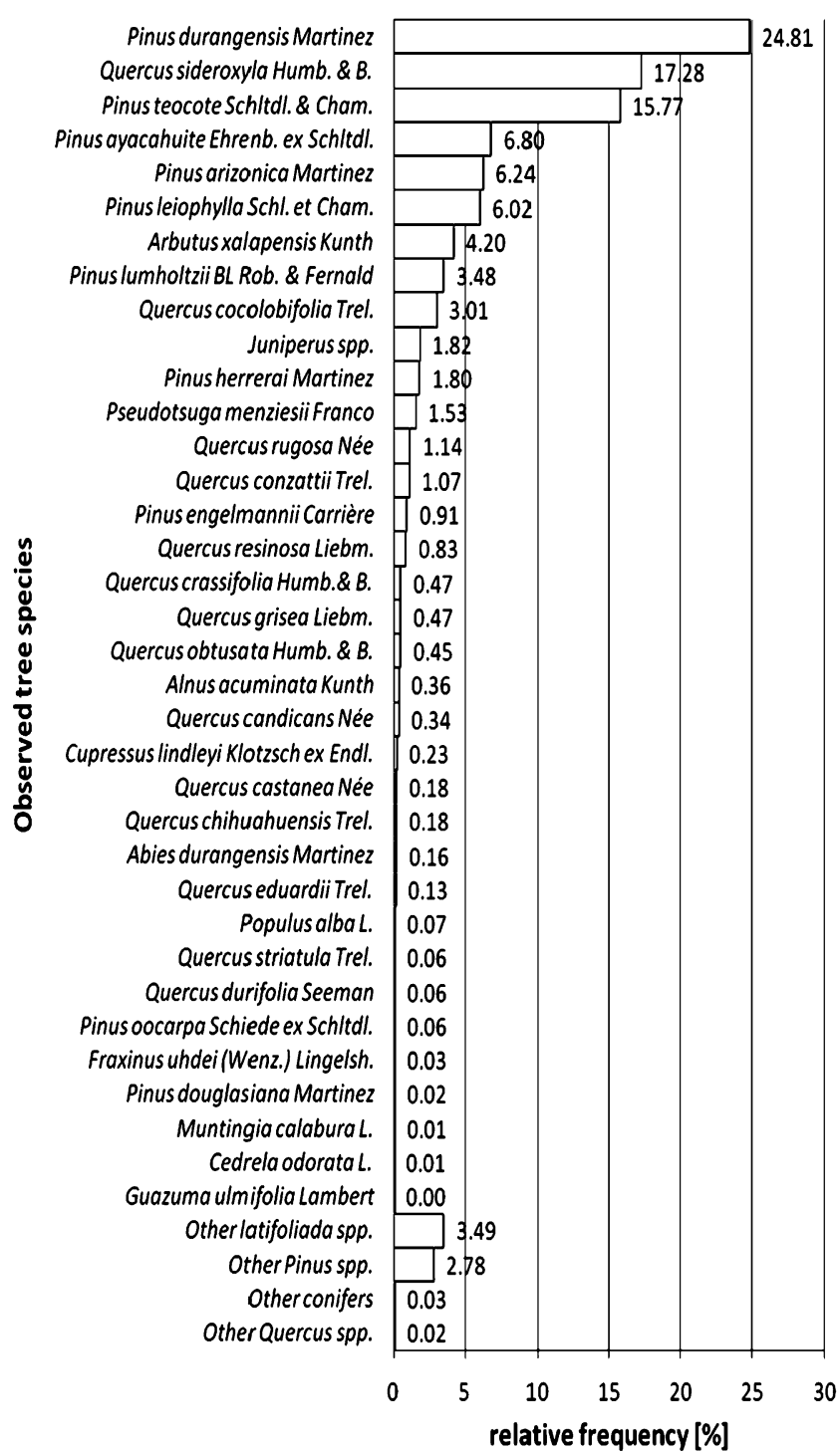

Fig. 1 Species distribution of all trees with $D B H$ exceeding $10 \mathrm{~cm}$ in the 17,577 sample plots. The total area of all sample plots is 1,674 ha

durangensis Martinez, Quercus sideroxyla Humb. \& B., and Pinus teocote Schltdl. \& Cham.

Disregarding the tree species, the relative $D B H$ frequencies $(f)$ in diameter classes 12 to $57 \mathrm{~cm}$ decrease nearly perfectly monotonously. The total covariance $(C[D C \times f])$ is -0.9999 and the $P$ value $P(Z \geq C)$ less than 0.0001 . Only trees in the $39 \mathrm{~cm}$ diameter class did not follow the general trend of monotonous decrease (Fig. 2).

The overall $D B H$ distribution in Fig. 2 shows a reverse $J$-shaped form, which is typical for uneven-aged forests. Diameter classes 12,42 , and $48 \mathrm{~cm}$ are under-represented and the classes with midpoints 21 and $39 \mathrm{~cm}$ are overrepresented. The line in Fig. 2 is the graph of the exponential function $f=a \cdot e^{(b \cdot D C)}$ with coefficients $a=0.623$ and $b=-0.08$. The distance $(d)$ between the model and the empirical distributions is equal to 0.067 . This is a very low value, which indicates that only $6.7 \%$ needs to be exchanged to make the two distributions identical. On the basis of the random permutations, we can assume that the probability of rejecting the null hypothesis of identical distributions is equal to 0.285 , which is greater than the threshold value of 0.05 .

\subsection{Diameter distributions in different height classes}

The observed relative diameter distributions in the diameter classes between 12 and $57 \mathrm{~cm}$, for the 17 to 18 most frequently occurring tree species and four classes of maximum tree heights per stand $\left(H_{\max }\right)$, regardless of the tree species, are similar to a reverse $J$ distribution (Fig. 3).

The diameter distributions for single species are not usually perfectly balanced. However, when grouped together, they represent an almost perfectly balanced diameter distribution, which is consistent with the exponential function $f=a \cdot e^{(b \cdot D C)}$. The parameter values for the four height classes are shown in Table 1. The parameter values appear to follow a trend. The parameter $b$ increases, whereas $a$ decreases, with increasing $H_{\max }$.

The differences $(d)$ between the empirical and the model distributions are statistically identical only for the 25-29 $\mathrm{m} H_{\max }(d=0.044 ; p=0.005)$ and $30-40 \mathrm{~m} H_{\max }$ classes $(d=0.046 ; p=0.0002)$. Perfectly balanced $D B H$-class distributions of a single tree species in all plots are very rarely found. However, there are many "nearly" balanced $D B H$-class distributions (Fig. 3).

The largest covariation values +0.8421 and +0.9364 were observed for Pinus oocarpa, in two $H_{\max }$ classes.

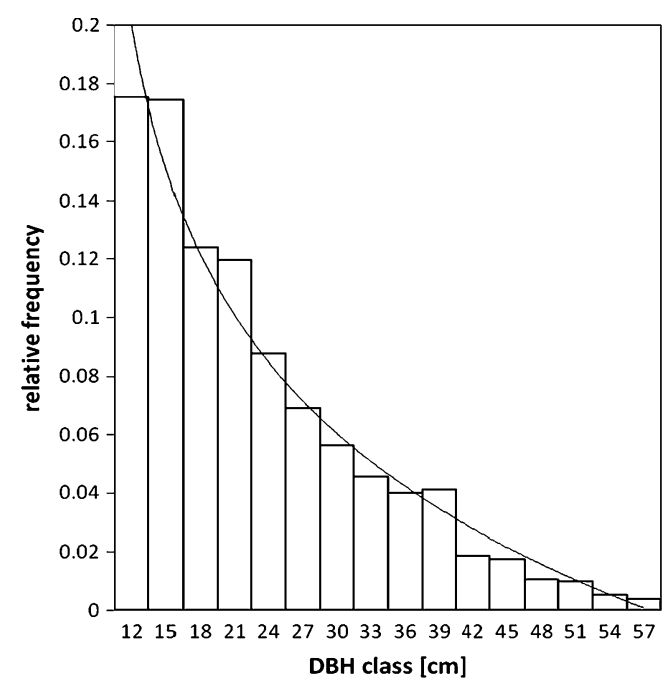

Fig. 2 The observed relative diameter distribution in the diameter classes of 12 to $57 \mathrm{~cm}$ for all sample plots $(17,577)$ and all tree species in an area of 1,674 ha 

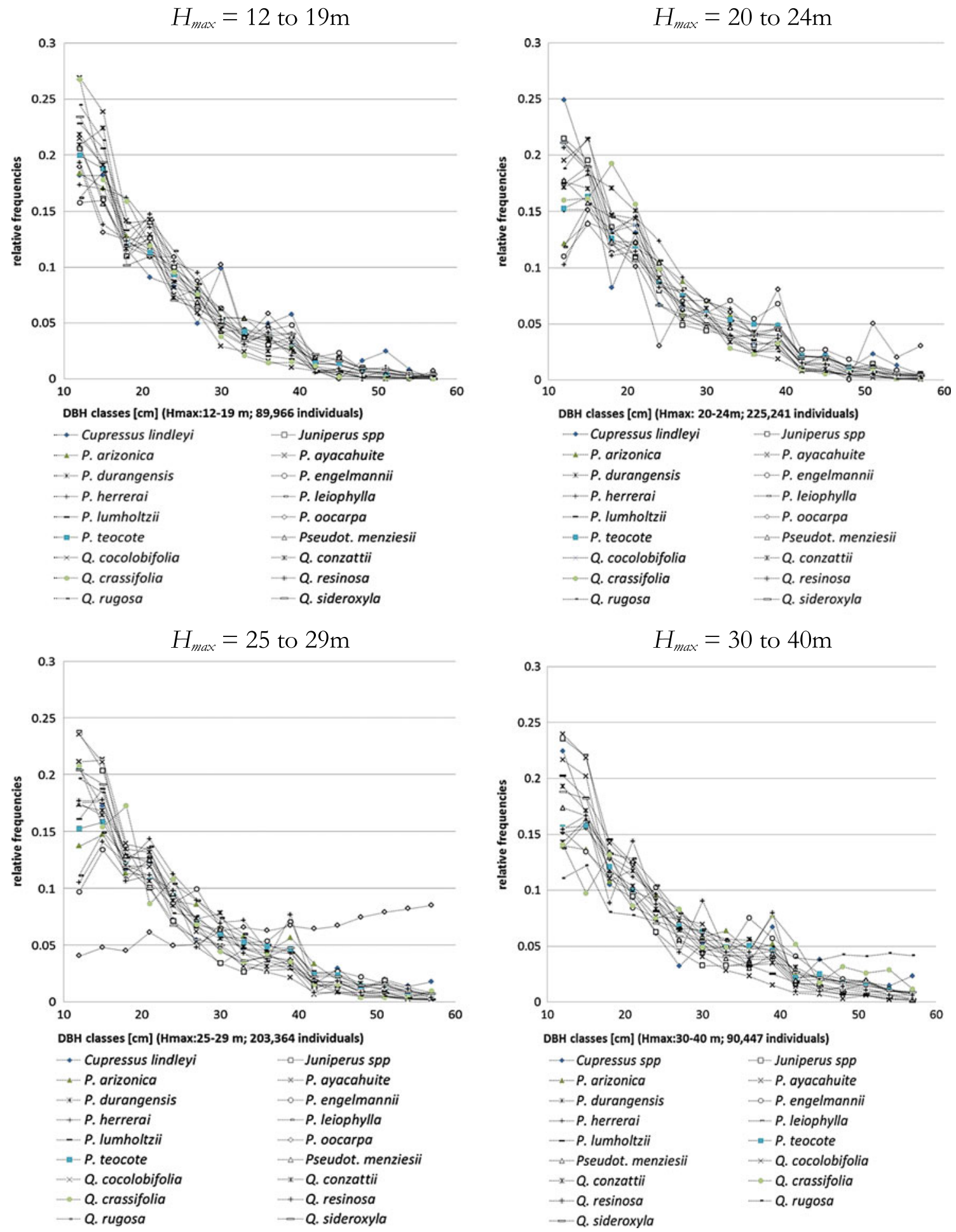

Fig. 3 Relative diameter distributions observed in the diameter classes of 12 to $57 \mathrm{~cm}$ of the 18 most frequent tree species and four classes of maximum tree heights per stand $\left(H_{\max }\right)$, regardless of tree species 
Table 1 Parameter values for the four height classes in the $12-57 \mathrm{~cm}$-diameter classes

\begin{tabular}{lll}
\hline$H_{\max }[\mathrm{m}]$ & $a$ & $b$ \\
\hline $12-19$ & 1.040 & -0.10 \\
$20-24$ & 0.756 & -0.09 \\
$25-29$ & 0.541 & -0.07 \\
$30-40$ & 0.450 & -0.06 \\
\hline
\end{tabular}

Covariation values of between -0.9835 and -0.9999 were found for most tree species, for all maximum tree heights. Three common pine species ( $P$. durangensis, Pinus ayacahuite, and Pinus arizonica) and two oak species (Quercus crassifolia and Quercus cocolobifolia) have a perfect covariation value of -1.0 .

The minimum areas and the minimum number of trees required for a covariation between the $D B H$ classes and their respective relative frequencies of less or equal to -0.99 are shown in Table 1. In addition, the $95 \%$ confidence intervals are shown for the minimum areas and the minimum number of trees required for a covariation $<-0.99$. The areas and numbers of trees per species that were observed for all sample plots are also shown in Table 2. The table, which has been sorted using the values in column 8 , shows the species attributes in ascending order. The smallest area corresponds to Pinus oocarpa and the largest to $P$. durangensis. The total number of trees per species found in the 17,577 plots without considering the conditions "balanced structure" and "viable population" are shown in column 7. The sum of all plots in which the particular species was found, again not considering the above two conditions, are shown in column 8 .

The $95 \%$ confidence intervals for the minimum structure areas $\left(B S A_{0.025} ; B S A_{0.975}\right)$, which provide a nearly balanced Three-cm $D B H$-class distribution $(C[D C \times N]<-0.99)$ in the

Table 2 Minimum balanced structure areas ( $B S A$, hectares) and structure tree numbers $(B S N)$ that provide a nearly balanced Three-cm $D B H$-class distribution (with $C[D C \times N]<-0.99$ ) in the interval of 12 to $57 \mathrm{~cm}$

\begin{tabular}{|c|c|c|c|c|c|c|c|c|c|}
\hline Tree species & $\begin{array}{l}B S A \\
0.025[\mathrm{ha}] \\
1\end{array}$ & $\begin{array}{l}\text { Mean } \\
B S A[\mathrm{ha}] \\
2\end{array}$ & $\begin{array}{l}B S A \\
0.975 \text { [ha] } \\
3\end{array}$ & $\begin{array}{l}B S N \\
0.025 \\
4\end{array}$ & $\begin{array}{l}\text { Mean } \\
B S N \\
5\end{array}$ & $\begin{array}{l}B S N \\
0.975 \\
6\end{array}$ & $\begin{array}{l}\text { Absolute } \\
\text { frequency }[N] \\
7\end{array}$ & $\begin{array}{l}\text { Area } \\
{[\text { ha] }} \\
8\end{array}$ & $\begin{array}{l}\text { Stand density } \\
{[N / \mathrm{ha}]} \\
9\end{array}$ \\
\hline Pinus oocarpa Schiede ex Schltdl. & 3.30 & 7.16 & 13.30 & 73 & 161 & 303 & 409 & 14.80 & 28 \\
\hline Abies durangensis Martinez & 1.85 & 6.14 & 11.25 & 88 & 264 & 510 & 1,169 & 24.40 & 48 \\
\hline Quercus castanea Née & 0.85 & 6.29 & 23.20 & 74 & 265 & 935 & 1,328 & 26.45 & 50 \\
\hline Quercus chihuahuensis Trel. & 1.45 & 6.35 & 15.65 & 79 & 247 & 625 & 1,317 & 32.15 & 41 \\
\hline Quercus eduardii Trel. & 2.80 & 7.68 & 14.45 & 82 & 133 & 225 & 945 & 46.25 & 20 \\
\hline Quercus candicans Née & 1.55 & 5.25 & 17.35 & 78 & 203 & 832 & 2,455 & 56.85 & 43 \\
\hline Quercus crassifolia Humb.\& B. & 1.00 & 4.14 & 12.50 & 83 & 201 & 759 & 3,426 & 60.00 & 57 \\
\hline Cupressus lindleyi Klotzsch ex Endl. & 2.75 & 9.90 & 19.00 & 83 & 217 & 442 & 1,658 & 63.15 & 26 \\
\hline Quercus grisea Liebm. & 0.95 & 7.52 & 18.95 & 85 & 370 & 932 & 3,391 & 64.45 & 53 \\
\hline Quercus obtusata Humb.\& B. & 1.15 & 7.31 & 25.55 & 79 & 314 & 1,066 & 3,273 & 66.65 & 49 \\
\hline Quercus resinosa Liebm. & 1.45 & 10.62 & 40.95 & 84 & 388 & 1,635 & 5,985 & 145.25 & 41 \\
\hline Quercus conzattii Trel. & 0.80 & 6.56 & 27.75 & 79 & 243 & 793 & 7,725 & 151.95 & 51 \\
\hline Pinus engelmannii Carrière & 1.85 & 24.79 & 96.45 & 77 & 849 & 3,255 & 6,599 & 176.05 & 37 \\
\hline Quercus rugosa Née & 1.25 & 4.61 & 16.15 & 77 & 160 & 481 & 8,194 & 180.70 & 45 \\
\hline Pinus herrerai Martinez & 0.70 & 27.81 & 112.80 & 86 & 1,697 & 7,743 & 13,017 & 193.40 & 67 \\
\hline Pseudotsuga menziesii Franco & 1.00 & 5.50 & 18.45 & 82 & 238 & 906 & 11,026 & 203.65 & 54 \\
\hline Quercus cocolobifolia Trel. & 0.90 & 4.07 & 17.00 & 79 & 189 & 756 & 21,747 & 374.65 & 58 \\
\hline Pinus lumholtzii BL Rob. \& Fernald & 1.00 & 15.72 & 119.20 & 81 & 540 & 3,773 & 25,078 & 472.00 & 53 \\
\hline Pinus leiophylla Schltdl. \& Cham. & 0.40 & 9.36 & 51.80 & 80 & 579 & 2,956 & 43,415 & 494.95 & 88 \\
\hline Pinus arizonica Martinez & 0.50 & 12.20 & 104.10 & 81 & 694 & 5,013 & 44,992 & 544.85 & 83 \\
\hline Juniperus spp & 3.10 & 10.66 & 44.10 & 78 & 200 & 772 & 13,101 & 589.75 & 22 \\
\hline Pinus ayacahuite Ehrenb. ex Schltdl. & 1.35 & 11.36 & 121.55 & 82 & 513 & 5,929 & 49,054 & $1,087.45$ & 45 \\
\hline Quercus sideroxyla Humb. \& B. & 0.60 & 5.64 & 30.40 & 89 & 467 & 2,332 & 124,687 & $1,246.00$ & 100 \\
\hline Pinus teocote Schltdl. \& Cham. & 0.60 & 11.24 & 106.55 & 82 & 752 & 7,074 & 113,782 & $1,308.45$ & 87 \\
\hline Pinus durangensis Martinez & 0.55 & 12.37 & 116.35 & 84 & 998 & 8,981 & 179,036 & $1,577.05$ & 114 \\
\hline
\end{tabular}

In the form of the mean minimum balanced structure areas (mean $B S A$ ) and the mean minimum balanced structure tree numbers (mean $B S N$ ), the $95 \%$ confidence intervals of minimum balanced structure areas $\left(B S A_{0.025} ; B S A_{0.975}\right)$ and minimum balanced structure tree numbers $\left(B S N_{0.025}\right.$; $\left.B S N_{0.975}\right)$, the smallest and largest minimum balanced structure areas $\left(B S A_{\min } ; B S A_{\max }\right)$, and minimum balanced structure tree numbers $\left(B S N_{\min }\right.$; $B S N_{\max }$ ) of the conifer and oak species attaining a $C[D C \times N]<-0.99$ including all plots as well as the absolute frequency (tree number), area, and stand density over all sample plots 
Table 3 Covariation values of the mean minimum balanced structure tree number (mean BSN) and upper limit of the $95 \%$ confidence interval of the minimum balanced structure tree number $\left(B S N_{0.975}\right)$ with relative frequency, area (showing the geographical distribution of the particular species), and stand density of conifer and oak species investigated, and error probabilities $P(Z \geq C)$, calculated from 5,000 permutations

\begin{tabular}{llcccc}
\hline & Covariation $C$ & Mean $B S N$ & $P(Z \geq C)$ & $B S N$ 0.975 & $P(Z \geq C)$ \\
\hline Conifers & Relative frequency [\%] & 0.613 & 0.1130 & $0.953^{* *}$ & 0.0008 \\
& Area [ha] & 0.434 & 0.1833 & $0.893^{* *}$ & 0.0037 \\
& Density [N/ha] & 0.779 & 0.0232 & $0.903^{* *}$ & 0.0020 \\
Oak species & Relative frequency [\%] & 0.882 & 0.0626 & 0.952 & 0.0346 \\
& Area [ha] & 0.795 & 0.0805 & 0.915 & 0.0341 \\
& Density [N/ha] & 0.807 & 0.0340 & 0.871 & 0.0233 \\
\hline
\end{tabular}

Two asterisks $\left({ }^{* *}\right)$ indicate a significant degree of $C$ at a probability level of $1 \%$.

$D B H$ interval of 12 to $57 \mathrm{~cm}$, vary from 0.4 to $122 \mathrm{ha}, 1.2 \pm$ 0.6 to $21.7 \pm 8.3$ ha over all oak species and $1.5 \pm 1.0$ to $71.9 \pm$ 45.8 ha over all conifers in the unweighted average investigated. The values for conifers vary widely for different species and are on average twice as high as the values found for oaks. The $95 \%$ confidence intervals for minimum balanced structure tree number $\left(B S N_{0.025}\right.$; $B S N_{0.975}$ ) ranged between 73 and $8981,81 \pm 4$ to $948 \pm 552$ for all oak species and $81 \pm 4$ to $3666 \pm 3052$ for all conifers in the unweighted average investigated.

The covariation values of the minimum balanced structure tree number (Mean BSN) are shown in Table 3; these are required to attain a balanced diameter distribution and upper limit of the $95 \%$ confidence interval of the minimum balanced structure tree number $\left(B S N_{0.975}\right)$ with relative frequency, area, and stand density of conifer and oak species investigated, and probabilities of error $P(Z \geq C)$ calculated from 5,000 permutations. The results demonstrate that the $B S N_{0.975}$ increased significantly with the predominance (relative frequency), prevalence (area size), and density (individuals per area) of the tree species in the stand.

An example of how this approach may be used to estimate both the $B S A$ and $B S N$ that provide a nearly balanced three-cm $D B H$-class distribution in a forest stand in the study area is shown in Table 4. The idea is to merge individual stands into sustained-yield units using unevenaged silviculture. The forest subcompartment contains five tree species and was selected from the inventory data. The results indicate that the minimum area required for sustainable management is equal to $7.7 \mathrm{ha}$. This is the area required for a balanced diameter structure of Juniperus spp., the species that requires most space within the stand. The $B S N$ results show that each species requires different numbers of trees in order to reach a balanced $D B H$-class distribution. Both $B S A$ and $B S N$ are consistent within the 95\% confidence intervals shown in Table 3.

\section{Discussion}

The present study has shown that more than 60 different tree species occur within the study area (Fig. 1). Vargas (2006) obtained very similar results in the region of El Salto, which is located in the Sierra Madre Occidental, between a latitude of $23^{\circ} 30^{\prime}$ and $24^{\circ} 15^{\prime}$ north, and a longitude of $105^{\circ} 15^{\prime}$ and $105^{\circ} 45^{\prime}$ west, $100 \mathrm{~km}$ southwest of the city of Durango. The composition of tree species was slightly different in the earlier study.

The $D B H$ distributions in the present study predominantly show the reverse $J$-shaped form, which is typical for uneven-aged forests (Figs. 2 and 3) and is due to the extensive area with complex structure forest stands. Different forms of $D B H$ distributions may be found in smaller uniformly structured forest stands (Goff and West 1975). However, some stands might be too small to include all the successional stages and thus might over-represent certain structural features (Westphal et al. 2006).

When all plots are combined, the $D B H$-class distributions of many tree species are quite balanced (Figs. 2 and 3). The areas were sufficiently large to provide a permanent

Table 4 Balanced structure areas (BSA, hectares) and structure tree numbers $(B S N)$ that provide a nearly balanced three-cm $D B H$-class distribution (with $C[D C \times N]<-0.99$ ) in the interval of 12 to $57 \mathrm{~cm}$ in real forest stand in the study area

\begin{tabular}{lcc}
\hline Tree species & BSA (ha) & BSN $(N)$ \\
\hline Pinus durangensis & 2.5 & 121 \\
Pinus teocote & 6.8 & 186 \\
Pinus ayacahuite & 3.2 & 143 \\
Juniperus spp & 7.7 & 150 \\
Quercus sideroxyla & 3.4 & 216 \\
\hline
\end{tabular}


dynamic equilibrium of a mosaic of regeneration units (Korpel 1982; Koop 1989).

The $95 \%$ confidence intervals of minimum balanced structure areas $\left(B S A_{0.025} ; B S A_{0.975}\right)$, which provide a nearly balanced three-cm $D B H$-class distribution in the interval of 12 to $57 \mathrm{~cm}$ range between 0.40 ha and $122 \mathrm{ha}$, depending on the tree species. For the oak species, the area ranges between $1.2 \pm 0.6$ and $21.7 \pm 8.3$ ha, and for the conifers, between $1.5 \pm 1.0$ and $71.9 \pm 45.8$ ha. The $95 \%$ confidence intervals of minimum balanced structure tree number $\left(B S N_{0.025} ; B S N_{0.975}\right)$ vary from 73 to 8,981 , from $81 \pm 4$ to $948 \pm 552$ over all oak species and from $81 \pm 4$ to $3666 \pm$ 3,052 over all conifers (Table 2). There are no comparable studies in Mexico, so that we compared the results with those of studies in other countries. For northern German acid and mesotrophic beech forests (Fago-Quercetum and MilioFagetum) and the oak-hornbeam forests (Stellario-Carpinetum), the $B S A$ was reached in areas of 40,25 , and 10 ha, respectively (Koop 1981). According to Korpel (1982), in Slovakia for beech forests (Fagetum typicum), for mixed firbeech forests (Fagetum-abietosum and Abieto-Fagetum) and for spruce forests in the high-altitude zone (SorbetoPiceetum), the $B S A$ was $30,40-50$, and $60-70$ ha, respectively. The comparison shows that the oak-hornbeam forests investigated by Koop (1981) and the Mexican oak species exhibit similar mean $B S A$ values. In addition, the mean values of conifers varied only slightly from those in European studies.

We are not aware of comparable investigations involving the minimum $B S N$. However, the $B S N$ seems to be more significant in genetic and demographic studies as well as conservation biology research (Wright 1938; Nunney and Campbell 1993; Frankham 1996) than the BSA. The area alone is not meaningful because a given area may contain a few or many individuals. This also raises the interesting question as to whether $B S N$ (as an indicator of demographic sustainability) can be used to estimate the $M V P$, which is an indicator of "genetic sustainability", an attribute that is difficult to measure.

The $B S N$ is positively correlated with the relative frequency, area, and stand density of the tree species (Table 3). Protected species, such as Abies durangensis and Pseudotsuga menziesii, and rare species (Table 2) have a lower $B S N$ than most of the important commercial tree species. These include P. arizonica, $P$. durangensis, Pinus leiophylla, Pinus engelmannii, P. teocote, Pinus herrerae and some species of the genus Quercus (Corral-Rivas 2006). These species are commercially important, not only because of the good quality of their timber, but also because they occur more frequently and are more widely distributed. Because of their commercial value, these species may have been harvested so heavily in some areas in previous selective thinnings that more trees are required for a balanced distribution. Additionally, the shelterwood system practiced in some of these forests may result, sometimes unintentionally, in structural modification of the populations, thus generating uniform stand structures. Stand density may also directly influence the $B S N$ by affecting the growth of recruitment trees (Schütz 2002, 2006). One way to investigate this effect would be to compare the present results with those from areas that have been completely protected for long periods of time.

The estimates of minimum structure areas presented here have potentially important implications for forest management: (1) compared with traditional approaches in unevenaged silviculture, sustainable forest conditions are evaluated in a more comprehensive way by considering both $B S A$ and $B S N$; (2) this study has shown that it is possible to identify silvicultural treatments that are conducive to sustainable use most effectively at the species level; (3) future management monitoring in the unique forests of Durango, based on a forest inventory with a large number of sample plots, will reveal unsustainable harvesting practices more effectively and in a more comprehensive way than before, using the methods presented in this study.

Acknowledgments This study was generously supported by El Fondo de Cooperación Internacional en Ciencia y Tecnología entre la UE-México (project: 92739). We gratefully acknowledge the support offered by the technical directorate of the Ejido "San Diego de Tezains" who provided the data for this study.

\section{References}

Baker JB, Cain MD, Guldin JM, Murphy PA, Shelton MG, (1996) Uneven-aged silviculture for the loblolly and shortleaf pine forest cover types, United States Department of Agriculture, Forest Service, Southern Research Station, Gereral Technical Report SO-118, p 65

Bücking W (2003) Are there threshold numbers for protected forests? J Environ Manage 67:37-45

Buongiorno J, Gilles JK (2003) Decision methods for forest resource management. Academic, San Diego, p 439

Cancino J, Gadow Kv (2002) Stem number guide curves for unevenaged forests - development and limitations, In: Gadow Kv, Nagel J, Saborowski J 2001. Continuous Cover Forestry-Assessment, Analysis, Scenarios, Kluwer

Corral-Rivas JJ (2006) Models of tree growth and spatial structure for multi-species, uneven-aged forests in Durango (Mexico), $\mathrm{PhD}$ thesis, University of Göttingen

Corral-Rivas JJ, Sánchez S, Kotze H, Gadow K (2009) Testing the suitability of the Nepal-Somers stand table projection method for Eucalyptus grandis plantations in South Africa. Southern Forests: J For Sci 71(3):207-214

FAO (1998) http://www.fao.org/UNFAO/Bodies/NAFC/nafc98/ NAFC4-E.HTM

Frankham R (1996) Relationship of genetic variation to population size in wildlife. Conserv Biol 10(6):1500-1508

Gadow Kv, Hui GY (2007) Can the tree species-area relationship be derived from prior knowledge of the tree species richness? Forest Stud Metsanduslikud Uurimused 46:13-22 
Gadow Kv, Puumalainen J (2000) Scenario planning for sustainable forest management. In: Gadow Kv, Pukkala T, Tomé M (eds) Sustainable forest management. Kluwer Academic Publisher, Dordrecht, pp 319-356

García E (1989) Modificaciones al sistema de clasificación climática de kôpen (para adaptarlo a las condiciones de la República Mexicana). Offset Larios, México D.F., 165

Goff FG, West D (1975) Canopy-understory interaction effects on forest population structure. For Sci 21:98-108

Gregorius HR, Degen B, König A (2007) Problems in the analysis of genetic differentiation among populations - a case study in Quercus robur. Silvae Genet 56:190-199

Guldin JM (1991) Uneven-aged BDq regulation of Sierra Nevada mixed conifers. West J Appl For 6(2):27-32

Hubbell SP (2001) The unified neutral theory of biodiversity and biogeography. Princeton University Press, Princeton

Koop H (1981) Vegetatiesstructuur en dynamiek van twee natuurlijke bossen: het Neuenburger en Hasbrucher Urwald, Verslagen van landbouwkundige onderzoekingen 904 PUDOW Wageningen

Koop H (1989) Forest dynamics-SILVI-STAR: a comprehensive monitoring system. Springer, Berlin

Korpel S (1982) Degree of equilibrium and dynamical changes of the forest in example of natural forests of Slovakia. Acta Fac For 24:9-13

Kotwal PC, Omprakash MD, Kandari LS, Mali KP, Badyal M, Mishra A (2008) Sustainable forest management through community participation. Curr Sci 95(8):1015-1017

Kurth H (1994) Forsteinrichtung. Nachhaltige Regelung des Waldes, Deutscher Landwirtschaftsverlag. Berlin, p. 592

Lawton JH (1999) Are there general laws in ecology? Oikos 84 (2): $177-192$

Meyer HA (1933) Eine mathematische Untersuchung über den Aufbau des Plenterwaldes. Schweiz Z Forstwes Zürich 84:33, 88,124

Nunney L, Campbell KA (1993) Assessing minimum viable population size: demography meets population genetics. Trends Ecol Evol 8:234-239

Nyland RD (2002) Silviculture. Concepts and applications, 2nd edn. McGraw-Hill, New York

Rajora OP (1999) Genetic biodiversity impacts of silvicultural practices and phenotypic selection in white spruce. Theor Appl Genet 99:954-961
Rodríguez CR (1958) Discusión de fórmulas para el cálculo de la productividad maderable y exposición del Método Mexicano de Ordenación de Montes de especies coníferas, Monografía Ftal. del Edo. de Michoacán, Comisión Ftal. del Estado, p 245

Rzedowski J (1978) Vegetación de México. Limusa, México

Schütz JP (2002) Silvicultural tools to develop irregular and diverse forest structures. Forestry 75:329-337

Schütz JP (2006) Modelling the demographic sustainability of pure beech plenter forests in Eastern Germany. Ann For Sci 63:93100

Secretaría de Recursos Naturales y Medio Ambiente (SRNyMA) (2002) Programa Estratégico Forestal 2030, Secretaría de Recursos Naturales y Medio Ambiente del Estado de Durango. Durango, Dgo., p 242

Seymour RS, Kenefic LS (1998) Balance and sustainability in multiaged stands: a northern conifer case study. J Forest 96:12-17

Silva-Flores R, Hernández-Díaz P, Corral-Rivas JJ, Wehenkel C, Vargas-Larreta B (2010) Species-specific abundance, tree diversity and its relationship to climate factors in mixed and unevenaged forests of Durango, Mexico. In: Kleinn C, Fehrmann L (eds) Proceedings of the Workshop "Forests in climate change research and policy: The role of forest management and conservation in a complex international setting. Göttingen, Germany, pp. 70-77

Thoms CA, Betters DR (1998) The potencial for ecosytems management in Mexico's forest ejidos. For Ecol Manage 103:149-1179

Tjørve E (2003) Shapes and functions of species-area curves: a review of possible models. J Biogeogr 30:827-835

Torres RJM (2000) Sostenibilidad del volumen de cosecha calculado con el método de ordenación de montes. Madera y Bosques 6 (2):57-72

Vargas LB (2006) Analyse und Prognose des Einzelbaumwachstums in Strukturreichen Mischbeständen in Durango, Mexiko, PhD thesis Univ. Göttingen, p 173

Westphal C, Tremer N, Oheimb vG, Hansen J, Gadow vK, Härdtle W (2006) Is the reverse J-shaped diameter distribution universally applicable in European virgin beech forests? For Ecol Manage 223(1-3):75-83

Williams MR (1995) An extreme-value function model of the species incidence and species-area relationship. Ecology 76:2607-2616

Wright S (1938) Size of population and breeding structure in relation to evolution. Science $87: 430-431$ 